\title{
A HAZAI TANÁRKÉPZÉS: DIAGNÓZIS ÉS JAVASLATOK
}

\author{
HATVANi LÁSZLó \\ a Szegedi Tudományegyetem Természettudományi Karának \\ egyetemi tanára, \\ az MTA Oktatási Stratégia Munkacsoport \\ koordinátora \\ hatvani@math.u-szeged.hu
}

Az MTA Pálinkás József elnök úr kezdeményezésére stratégiaalkotó tevékenységet indított el az ország jövőjét meghatározó területeken, így az oktatásügyben is. A Munkacsoportnak 36 tagja van, akiket az MTA tudományos osztályai delegáltak; elnök úr engem bízott meg a munka koordinálásával. A következö négy témában dolgoznak részmunkacsoportok egymással párhuzamosan:

- felsőoktatás,

- tanárképzés, pedagógushelyzet,

- közoktatás,

- oktatástudomány, oktatásirányítás.

A tanárképzés a felsőoktatásnak része, mégis külön témaként kezeljük, ugyanis az oktatási folyamat föszereplője a diák, de kulcsszereplöje a tanár, akin az oktatás minősége múlik. A tanárképzéssel foglalkozó részcsoport munkáját is én koordinálom. A stratégiaalkotás folyamatban van. Az egyes témákban már megszületett anyagok akkor tekinthetők majd az MTA hivatalos állásfoglalásának, ha a Munkacsoport plenáris ülése azokat elfogadta. Az általam ma kifejtendő gondolatokat ezért kérem, tekintsék egyenlöre szubjektív véleménynek.

Egy egészen rövid történeti áttekintéssel szeretném kezdeni az előadást. A II. világháború előtt a gimnáziumi tanulmány kevesek kiváltsága volt, a gimnáziumokban lényegében elitképzés folyt, az itt oktató pedagógusok közül sokan a „tudós tanár” eszményképének is megfeleltek, és igen magas szakmai színvonalú tanárképzésen estek át. Ezt alátámasztja az a tény, hogy akkor a kutatóképzés és a tanárképzés még nem vált szét az egyetemeken. Azt is el lehet mondani, hogy a tanárok társadalmi (anyagi és erkölcsi) megbecsülése is magas szintü volt.

A II. világháború után a gimnáziumi tanulmányokat folytatók száma drasztikusan megnőtt, ezt követte a tanárképzés volumenének növekedése. Különvált a kutatóképzéstől, ami a szakmai színvonal csökkenését jelentette, de ez a színvonal azért még mindig elég magas volt nemzetközi összehasonlításban is. Kialakult egy jól müködő és színvonalas duális tanárképzés. Fontos változás volt viszont határozottan negatív irányban a tanárok társadalmi megbecsültségének drasztikus csökkenése, még 
a többi értelmiségi pályával való összehasonlításban is. Ez egy határozottan érzékelhető kontraszelekciós folyamatot indított el, ami a későbbi válság gyökere lett.

A rendszerváltoztatás után ugyanis a tanárképzés súlyos válságba került, amelynek számos oka van. Ezek közül véleményem szerint a legsúlyosabb a társadalmi megbecsültség további csökkenése, ami tovább erősítette a kontraszelekciós folyamatot, bizonyos fontos intézmények (pl. szakfelügyeleti rendszer) megszünése, bizonyos közösségek (évfolyamok, kollégiumok) fellazulása, eltünése, a túlzott liberalizálás káros hatása többek között a tankönyvek, tantervek, vizsgarendszerek területén, amely kaotikus viszonyok kialakulásához vezetett.

Ezt követte 2006-ban a tanárképzés alapvető reformja a bolognai kétciklusú rendszeren belül, amely - ahelyett, hogy javított volna a helyzeten - csak súlyosbította a válságot. Hangsúlyozni szeretném, nem tartozom azok közé, akik a tanárképzés minden baját a bolognai-rendszer nyakába varrják, de azt határozottan állítom, hogy az egyébként is válságban lévő tanárképzést rossz irányba reformálta, tovább mélyítve a válságot. Felsorolok néhány érvet állításom indoklására:

- Az új rendszer bevezetése elsietett volt. Nem készültek hatástanulmányok, nem folytak előkészítő oktatási kísérletek, nem volt széles körü vita, az ellenvéleményeket az oktatásügy irányítói figyelmen kívül hagyták.

- Kibékíthetetlen ellentmondás van a kétlépcsős képzési rendszer és a minőségi kétszakos tanárképzés között. Ugyanis

- az első év végén esedékes szakirányválasztáskor a tanári szakirány választása szakmai zsákutca, amivel a hallgató kizárja magát tanulmányainak esetleg nem-tanári mesterszakon való folytatásából;

- a teljes 11 féléves képzést tekintve is a két szak diszciplináris ismereteinek vonatkozásában aszimmetria van, vagyis valójában „másfél szakos" tanárképzés folyik;

- az alapszak tanári szakirányát záró BA/BSc-diploma haszontalan, felesleges, idő- és energiapocsékolás.

- Az egységes tanárképzés lehetetlenné teszi a leendő tanárok felkészítését a tanulók különböző életkori sajátosságainak kezelésére az oktatásinevelési gyakorlatban.

- Az egységes tanárképzésról szóló törvény és a korábbi duális képzés minden intézményének fenntartása együtt, azt eredményezték, hogy túl sok helyen folyik hazánkban tanárképzés, a különböző intézmények közötti minőségi különbségeket a rendszer figyelmen kívül hagyja, a tanárképzés szakmai színvonala egységesen a korábbi föiskolai képzés színvonalára süllyedt.

Javaslatok a bolognai típusú tanárképzési rendszer hibáinak kiküszöbölésére:

- A tanárképzést ki kell venni a bolognai-rendszerből, mert abba sem tartalmilag, sem szerkezetileg nem illeszthetö bele. 
Ezen javaslat megvalósulásáig, részben egy új tanárképzési rendszert célzó előkészítő kísérletek jegyében, a következőket javasoljuk:

- Az alapszak első évének végén egy felvételi és szakmai alkalmassági vizsgát követően tegyük lehetővé egy egyciklusú kétszakos tanárszak felvételét az egyetemeken.

- A jelenlegi rendszerben MA/MSc után 3 félév alatt egyszakos tanári diploma szerezhető. Ehhez hasonlóan adjunk lehetőséget BA/BSc után 2 vagy 3 félév alatt általános iskolai tanári diploma megszerzésére a föiskolákon és egyetemeken.

- Újra kell gondolni az egységes tanárképzés intézményét. Biztosítani kell, hogy a tanárképzésbe beépüljön a tanulók különböző életkori sajátosságaiból adódó követelmények figyelembevétele.

Külön szeretnék foglalkozni az új tanárképzés egy, a bolognai-rendszertől független, első látásra technikainak tünő, de valójában súlyos szakmai következményekkel járó problémájával, nevezetesen a szakmai megjelölés nélküli egyetlen, egységes „tanári mesterképzési szak” (MA) intézményével. Ez azt jelenti, hogy amikor egy hallgató tanári mesterszakot választ, akkor nem mondhatja, hogy magyartörténelem, biológia-kémia, matematika-fizika, vagy pedagógia-játék- és szabadidő-szervező tanári szakra szeretne beiratkozni, mert a törvény csak az egyetlen „tanári mesterképzési szak” megnevezést ismeri; az előbb felsorolt területek a szakon belül úgynevezett egyenrangú „blokkok” csupán. Végzéskor mindenki ugyanazt az MA (Master of Arts!!) diplomát kapja. Egy intézményen belül a szaknak egyetlen szakfelelőse van, aki természetesen a neveléstudományok területéröl kerül ki, egyáltalán az intézmény neveléstudományi egysége (tanszéke, tanszékcsoportja) a felelős az egész tanárképzésért.

Mi ennek a rendszernek a következménye? Ennek az az üzenete, hogy a tanári mesterségre való felkészítésben a diszciplináris szakmai ismeretek kevésbé fontosak, mint a pedagógiai-pszichológiai ismeretek. A helyzetet egy hasonlattal szeretném érzékeltetni. Kíváncsi lennék müegyetemi kollégáim véleményére, ha valakik megszüntetnék az eddigi mérnöki szakokat, nem lenne vegyészmérnöki, gépészmérnöki, villamosmérnöki szak, helyette lenne egyetlen osztatlan „mérnöki szak”, és ezért az informatikai tanszékcsoport lenne felelős, hiszen informatikai ismeretekre minden mérnöki szakon szükség van. A képzelet világából a valóságba viszszatérve: a jelen rendszerben a tanárszakoknak nincs igazi, hozzáértő gazdája, az egyetlen szakfelelős és egysége logisztikailag is képtelen a szervezési feladatok ellátására, a hallgatók tájékozatlanok, nem kapnak információt. Ez a rendszer elijeszti a tanári szak választásától azokat a hallgatókat, akikben a tanári elhivatottság mellett szakmai ambíciók is vannak és magas szinten el akarják sajátítani, sőt müvelni is a választott tudományágukat. A képesítési és kimeneti követelmények, a kreditek elosztása azt mutatják, hogy a tanári mesterszakon a pedagógiai-pszichológiai tan- 
anyag szerepe túlhangsúlyos a szakmai tárgyak és a szakmódszertan rovására. Például, ismereteim szerint a tanári mesterszak záróvizsgáján kizárólagosan pedagógiai-pszichológiai ismeretek szerepelhetnek a tematikában, diszciplináris ismeretek és szakmódszertan egyáltalán nem.

Javaslatunk: meg kell szüntetni a szakmai megjelölés nélküli egységes tanári szakot és visszaadni a tanári szakok önállóságát (biológia tanári szak, matematika tanári szak,...). Mind az elnevezésekben, mind a felelősségek megjelölésében, mind a képesítési és kimeneti követelmények megfogalmazásában tükröződnie kell annak, hogy a tanári mesterségre való felkészítésben a szakmai (diszciplináris) képzés az elsödleges és meghatározó. Ugyanakkor le kell szögezni: a tanári mesterséghez szükség van pedagógiai és pszichológiai ismeretekre, de mérsékelni kell ezen tárgyak túlsúlyát a szakmailag indokolt mértékre. A viszony érzékeltetésére ismét egy képzeletbeli példát hozok fel. Tegyük fel, hogy valamilyen okból szükség van egy gimnáziumi matematikatanár helyettesítésére. Azt el tudom képzelni, hogy ezt a feladatot például egy olyan egyetemi matematikaoktatóra bízzuk, aki nem végzett pedagógiai stúdiumokat, de nem tudom elképzelni, hogy olyan személyre bízzuk, aki neveléstudományból a legmagasabban képzett, de a középiskola óta nem tanult matematikát.

A diszciplináris szakmai ismeretek fontosságánál kell megemlíteni a következő javaslatunkat is: érvényt kell szerezni az akkreditáció során annak az alapelvnek, hogy tanári diplomát csak olyan intézmény adhat, amelyben színvonalas kutatások folynak, és amely szakmai szempontból képes a legmagasabb szintủ oktatásra, jelesül az önálló, alkotó gondolkodásra nevelésre.

Végezetül minden indoklás, kifejtés nélkül, csupán távirati stílusban megemlítem néhány további javaslatunkat:

- Vonzóvá kell tenni a tanári pályát mind erkölcsi, mint anyagi szempontból, hogy megszünjön a kontraszelekció!

- Szigorú kiválasztási rendszert, követhető, kiszámítható követelményrendszert kell kidolgozni a tanárok számára!

- Újra kell szervezni a szakfelügyeleti rendszert!

- Újra kell szervezni a tanártovábbképzést!

- Ki kell alakítani egy tanári életpályamodellt, beleértve a tudományos kiemelkedés lehetőségét!

Szóltam az önálló gondolkodásra való nevelés fontosságáról. Előadásomat Eötvös Loránd egy gondolatával zárom: „Gondolkodásban önállóságot csak az olyan tanár tanítása adhat, aki maga is önállóan gondolkodik.” 